\title{
Eksperymentalna powłoka żelbetowa
}

\section{Waldemar Bober}

\author{
Wydział Architektury Politechniki Wroctawskiej
}

Streszczenie: W twórczości projektowo-badawczej Wacława Zalewskiego znajduje się zrealizowana w 1965 konstrukcja eksperymentalna sprężonej powłoki betonowej wiszącej na heksagonalnym układzie łuków stalowych. Ze względu na ówczesny brak odpowiednich narzędzi badawczych oraz projektowych, ta skomplikowana statycznie i technologicznie budowla powstała w sposób doświadczalny na podstawie założeń koncepcyjnych Zalewskiego, który jednocześnie sprawował nadzór nad jej realizacją. Dynamiczne działania techniczne podczas realizacji konstrukcji mogą być klasyfikowane jako wczesne przejawy rozwiniętego w ostatnich latach poszukiwania formy obiektu architektonicznego określanego mianem "form finding". Przeanalizowanie założeń technicznych oraz technologii wznoszenia tego interesującego obiektu stanowią cel niniejszego artykułu. Ze względu na brak dostępnej dokumentacji autor opierał się na informacjach zebranych podczas rozmów z Wacławem Zalewskim i uzyskanych od niego fotografiach z realizacji obiektu.

Słowa kluczowe: forma konstrukcji, powłoka żelbetowa

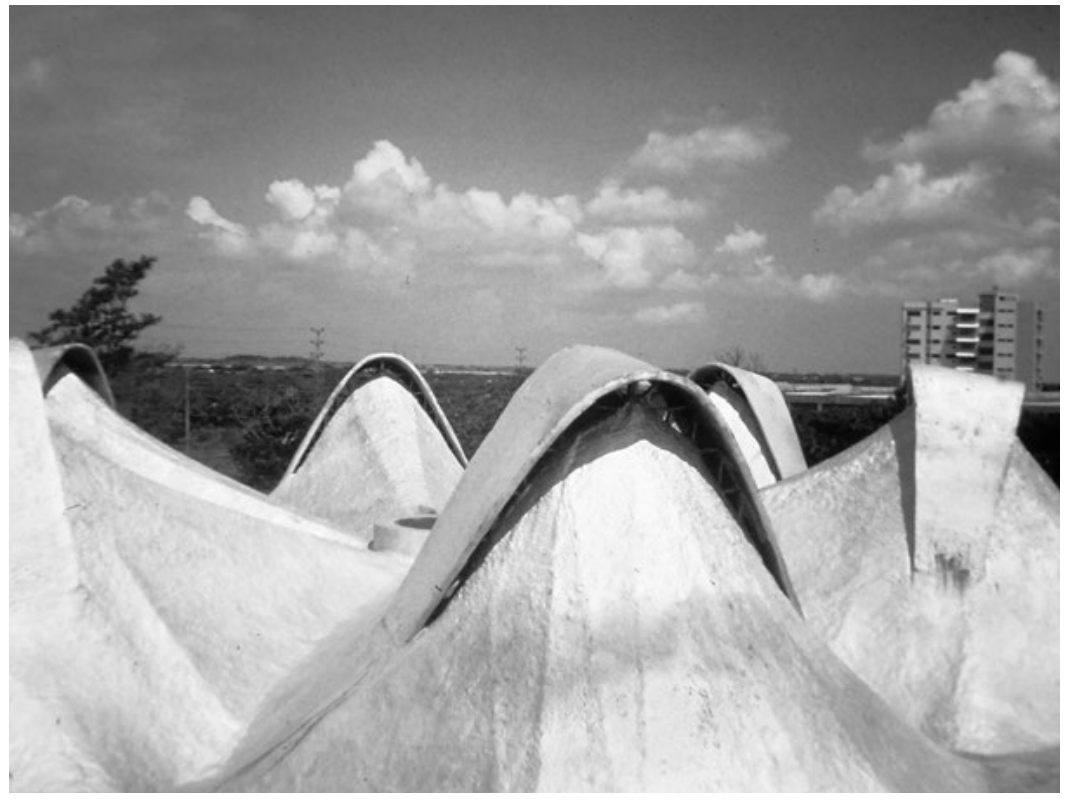

Ryc. 1. Widok zewnętrzny powłoki

\section{Wprowadzenie do twórczości Wacława Zalewskiego}

Wacław Zalewski (1917-2016) rozpoczął swoją działalność badawczo projektową w latach pięćdziesiątych XX wieku w projektowym „BISTYP” serią innowacyjnych rozwiązań konstrukcyjnych zrealizowanych w obiektach przemysłowych. Technologią, której poświęcił najwięcej uwagi były konstrukcje żelbetowe powłokowe o charakterze cienkościennym, zastosowane do przykryć modułowych hal produkcyjnych. W rozwiązaniach szczegółowych Wacław Zalewski często posługiwał się elementami prefabrykowanymi, często na placu budowy. 
Zainspirowany teoretycznymi pracami inżynierii niemieckiej opracował oryginalną metodę "strumieni sił" do analizowania wytężenia materiałów konstrukcyjnych w elementach powłokowych. W konstruowaniu przykryć dachowych Zalewski od początku swobodnie posługiwał się dualizmem układów konstrukcyjnych zbudowanych z płyt ciągłych lub płyt w układzie rusztowym. Dla dyskretnych układów strukturalnych zbudowanych z prętów na krawędziach pól wielokątnych dobierał geometrię wypływającą z koncentracji sił wewnętrznych. Ukoronowaniem pracy projektowo-badawczej Wacława Zalewskiego w Polsce było opracowanie koncepcji konstrukcji hali sportowo-widowiskowej w Katowicach, nazwanej popularnie „Spodkiem”. Należy podkreślić współautorski udział Zalewskiego w definiowaniu bryły tego budynku, który został wpasowany w teren o małej powierzchni pomiędzy wpływami skód górniczych, jednocześnie ukośne ukształtowanie ścian zewnętrznych zapewniało zmniejszenie zginania ich elementów konstrukcyjnych. Zaproponowane w koncepcji Zalewskiego przykrycie linowo-prętowe jest oceniane przez współczesnych badaczy mianem pierwszej w świecie konstrukcji „tensegrity", jednak w tej formie nie zostało zrealizowane. Podsumowaniem osiągnięć Wacława Zalewskiego w pierwszym okresie jego twórczości było wystąpienie na konferencji IASS (International Associations for Shell and Spatial Structures) w San Francisco w 1962 roku. Powszechne uznanie międzynarodowego środowiska naukowego przyniosło Zalewskiemu propozycję stanowiska profesora w MIT w Bostonie. Jednocześnie kontynuował on kontrakt na Uniwersytecie w Merida, podczas trwania którego zrealizował kilka następnych innowacyjnych rozwiązań konstrukcyjnych w Wenezueli. Praca naukowa profesora Wacława Zalewskiego w MIT zaowocowała wykształceniem wielu inżynierów i doktorów w dziedzinie architektury oraz wydaniem kilku współautorskich podręczników akademickich, już w okresie emerytalnym.

\section{Ukształtowanie przestrzenne}

Konstrukcja eksperymentalna na Uniwersytecie w Merida (Wenezuela) została zaprojektowana przez Wacława Zalewskiego pod wpływem modeli form strukturalnych autorstwa Honoracio Caminos. Prezentował on modele membran gumowych rozpiętych na sztywnym okręgu i wypiętrzanych przez układy punktowych podpór wewnętrznych deformujących płaską membranę gumową. Podpory miały formę prostych prętów realizujących słupy.

Zainspirowany tymi kształtami Wacław Zalewski zaproponował przykrycie przestrzeni ekspozycyjnej w kampusie Uniwersytetu na rzucie zbliżonym do koła o średnicy $36 \mathrm{~m}$. Rozpięta na pierścieniu zewnętrznym powłoka żelbetowa została w środku przykrycia zawieszona na podporach wewnętrznych. System podparcia powłoki stanowi układ sześciu łuków stalowych opartych na wierzchołkach regularnego sześciokąta, leżącego wewnątrz pierścienia obwodowego na planie przykrycia. Płaszczyzny łuków są odchylone na zewnątrz w kierunku pierścienia obwodowego konstrukcji przykrycia.

Zewnętrzny pierścień obwodowy został zrealizowany na wysokości około $3 \mathrm{~m}$ powyżej powierzchni terenu, umożliwiając dostęp do wnętrza utworzonej konstrukcji. W rzucie poziomym kształt okręgu został zdeformowany do układu sześciu łuków z końcami na linii okręgu, o promieniu mniejszym niż pierścień, w celu odsunięcia pierścienia od łuków podporowych w liniach ich przewyższenia. Zabieg ten powodował korzystne technologicznie zmniejszenie nachylenia powłoki żelbetowej. Pierścień zewnętrzny nie miał żadnych podpór pośrednich i w całości został podwieszony do układu linowego wiszącej powłoki przykrycia.

Wewnętrzny pierścień powłoki został zaprojektowany narzucie kołowym o średnicy około $3 \mathrm{~m}$. Takie położenie pierścienia wewnętrznego umożliwiało kontynuowanie synklastycznego ukształtowania powłoki. Do krawędzi obu pierścieni dochodzą liny nośne powłoki żelbetowej. Powłoka przykrycia ma kształt dopasowany do układu linowego zawieszonego na heksagonalnym układzie łuków stalowych i łączącego dwa pierścienie: zewnętrzny i wewnętrzny przykrycia.

W celu ustabilizowania położenia wysokościowego pierścienia wewnętrznego ukształtowano w kierunkach przekątnych sześciokąta linie załamań powłoki, biegnące bezpośrednio pomiędzy pierścieniami. Wzdłuż tych linii jest możliwy spływ wody opadowej spadającej na powierzchnię przykrycia, co umożliwia określenie ich liniami koszowymi, analogicznymi do występujących w klasycznych dachach wielopołaciowych.

Górna część stalowych łuków podparcia wewnętrznego stanowi również krawędź przełamania powierzchni przykrycia. W trakcie realizacji liny nośne zostały niezależnie zawieszone po obu stronach łuków nośnych. W celu osłonięcia tej krawędzi przed wpływami atmosferycznymi zostały wykonane odcinkowe zadaszenia zagięte równolegle do krzywizny łuków. W przestrzeni pod powierzchnią przykrycia widoczne są dolne odcinki 
łuków stalowych, które tworzą układ V-kształtnych słupów podpartych w narożach sześciokąta. Takie położenie podpór łukowych umożliwia znaczącą redukcję wartości poziomych sił reakcji podporowych. Łuki w układzie heksagonalnym zostały zbudowane z dwóch rozchylających się łuków stalowych powiązanych ze sobą elementami stalowymi w układzie kratownicowym. Uzyskane w ten sposób zwiększenie sztywności giętnej łuków w ich części zwornikowej było konieczne dla przeniesienia sił napięcia lin nośnych w fazie realizacji powłoki. W widoku zewnętrznym bryła wykonanego przykrycia tworzy powłokę wiszącą, spływającą z górnych odcinków sześciu łuków do wewnętrznego i zewnętrznego pierścienia kołowego. Przyjęty rozstaw lin nośnych wpływa na kształt powłoki, która nie jest ciągła w rozumieniu dwukrzywiznowej powierzchni geometrycznej, lecz posiada spłaszczenia pomiędzy liniami lin nośnych oraz widoczne krawędzie przełamania wzdłuż lin nośnych. Wyraźnym miejscem przerwania ciągłości powłoki jest odcinek jej oparcia w górnej części łuków stalowych. Wpływ technologii zaczepienia lin nośnych na łukach znacznie pomniejsza klarowność rozwiązania i wprowadza elementy obcych form przykrycia połączeń przez dodane zadaszenia jednokrzywiznowe, o powierzchniach równoległych do linii łuków parabolicznych.
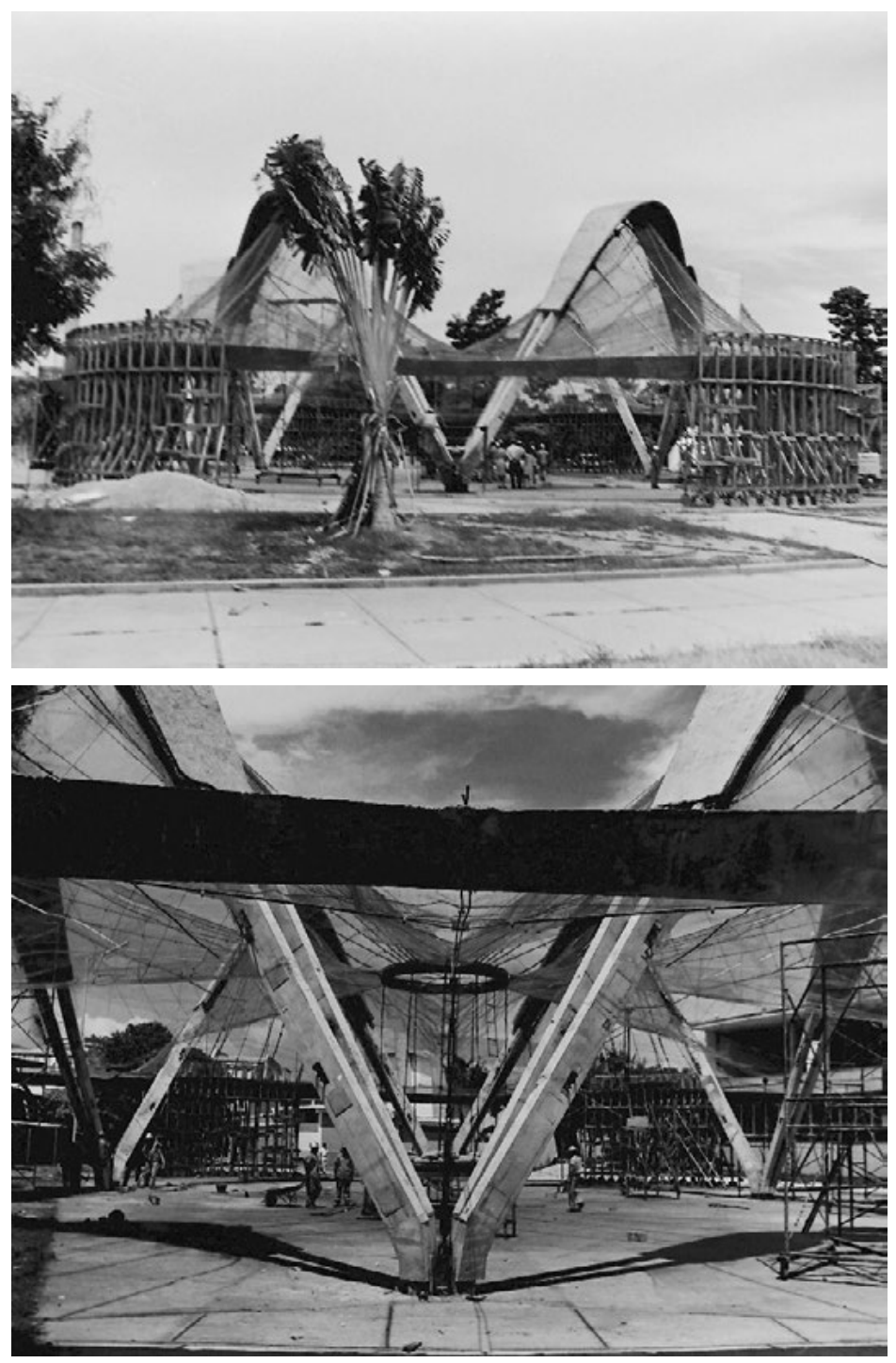

Ryc. 2. Ryc.2 i 3 System konstrukcyjny podparcia powłoki 


\section{Układ konstrukcyjny}

Fundamenty konstrukcji eksperymentalnej zostały wykonane jako bloki betonowe zagłębione w wierzchołkach sześciokąta, w punktach oparcia schodzących do podłoża łuków stalowych. Poziome siły reakcji podporowych sąsiednich łuków w dużej części się równoważą. Do przeniesienia na podłoże gruntowe pozostaje tylko składowa pionowa tych sił reakcji podporowych. Łuki paraboliczne w układzie heksagonalnym są podwójnymi łukami złożonymi ze stalowych przekrojów C-kształtnych. Paraboliczny kształt został przybliżony przez proste odcinki belek stalowych, połączonych ze sobą poprzez spawanie. Środkowe ścianki przekroju C zostały usytuowane od zewnętrznej strony w płaszczyźnie łuków. Rozchylające się ku górze łuki składowe połączono skratowaniem z prętów stalowych. Skratowanie wraz z konstrukcją samych łuków stalowych tworzy kratownicę przestrzenną, do której dolnego pasa podwieszono liny nośne powłoki. Miejsca podwieszenia lin dopasowano do węzłów konstrukcji kratowej w celu zmniejszenia zginania gałęzi łuków. Zadaszenie górnego odcinka łuków stalowych wykonano poprzez obetonowanie skratowanych gałęzi łuków z lekkim poszerzeniem poza łuki konstrukcji.

Zewnętrzny pierścień obwodowy powłoki wykonano jako koryto betonowe. Odcinki pierścienia pomiędzy łukami stalowymi zostały wykonane jako prefabrykowane. Odcinki na wprost łuków wylewano w trakcie realizacji powłoki.

Stalowe liny nośne o średnicy przekroju około $4 \mathrm{~cm}$ zostały zawieszone ze wstępnym wygięciem w stosunku do cięciwy zwisu. Ugięcie mierzone w pionie wewnątrz konstrukcji założono o wartości $1 \mathrm{~m}$, podczas gdy od wewnątrz przyjęto wstępne wygięcie liny $0,75 \mathrm{~m}$. Liny napinające w stosunku do lin nośnych założono prostopadle, tworząc pola układu linowego zbliżone do regularnych czworokątów. W układzie lin można wyróżnić kierunki radialne zbieżne do pierścienia środkowego powłoki. Połączenia utworzonej siatki linowej wykonano przy pomocy zacisków stalowych łączonych przy pomocy śrub. W celu ułożenia powłoki betonowej na układzie linowym rozwinięto siatkę stalową o małym wymiarze oczek. Ze względu na ręcznie układanie masy betonowej tworzącej powłokę uzyskano duże zróżnicowanie w poszczególnych fragmentach powłoki. Powłoka betonowa nie miała struktury jednorodnej i cechowała się warstwowością wynikającą z technologii jej układania. Istotnym aspektem utrzymania zaprojektowanego kształtu powłoki było dynamiczne balansowanie układu konstrukcji poprzez zmiany ciężaru pierścienia obwodowego zewnętrznego i wewnętrznego. W celu zapewnienia stateczności powłoki w trakcie układania betonu pierścień wewnętrzny był dociążony workami z piaskiem. Po stwardnieniu betonu powłoka pełniła rolę powierzchni nośnej i usztywniającej całość konstrukcji. Dwukrzywiznowy kształt powłoki wpłynął korzystnie na kompensację odkształceń powłoki wywołanych obciążeniem wiatrem, jak również obciążeniem termicznym wynikającym z nasłonecznienia powierzchni zewnętrznej powłoki. Wpływ nagrzewania został ograniczony poprzez pokrycie powłoki warstwą farby w kolorze srebra.

\section{Technologia wykonania}

Konstrukcja zadaszenia eksperymentalnego została wykonana przez pracowników grupy remontowej Uniwersytetu w Merida. Do wykonania elementów konstrukcyjnych wykorzystano dostępne na miejscu materiały budowlane w postaci belek stalowych, lin stalowych, siatek stalowych betonu na kruszywie z drobnego żwiru. Elementy konstrukcyjne łuków zostały połączone poprzez spawanie. Zwężające się do podparcia na przegubach łuki były stabilizowane w położeniu heksagonalnym za pomocą układu linowego. Zewnętrzny pierścień obwodowy został w części wykonany jako prefabrykowane koryto o zmiennym przekroju. Naprzeciwko łuków pierścień wykonano jako konstrukcję monolityczną, wylaną w deskowaniu drewnianym. Podczas betonowania powłoki przykrycia wewnętrzny pierścień stalowy był dodatkowo obciążany workami z piaskiem, w celu utrzymania naprężenia lin nośnych do czasu wykonania wewnętrznej części powłoki betonowej. Korekcję kształtu powłoki prowadzono poprzez odciążanie lin wciągarkami ręcznymi, mocowanymi do konstrukcji stalowych łuków. Betonowanie powłoki prowadzone było poprzez ręczne nakładanie kolejnych warstw zaprawy betonowej, obwodowo począwszy od pierścienia obwodowego powłoki. Właściwe naprężenie lin nośnych było na bieżąco korygowane poprzez zwiększenie zabetonowania koryta zewnętrznego pierścienia. Długotrwały proces ręcznego betonowania powłoki był prowadzony bez przerw technologicznych, co umożliwiało uzyskanie monolitycznej powłoki betonowej. 


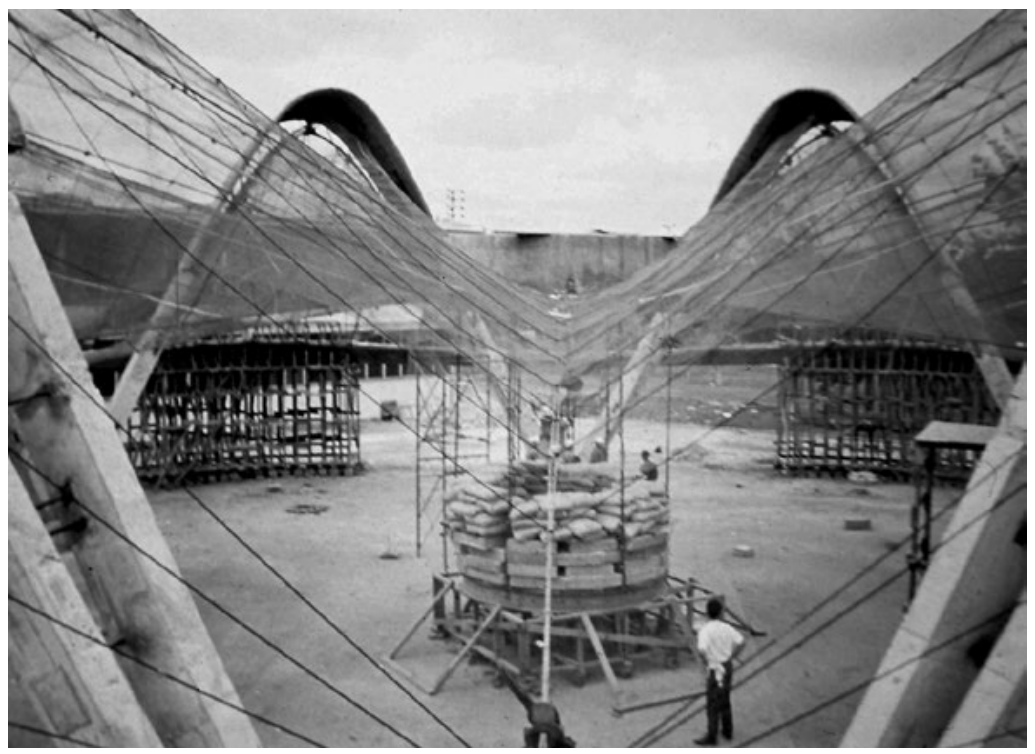

Ryc. 3. Balastowanie pierścienia wewnętrznego i lina koszowa

\section{Zachowanie konstrukcji w fazie eksploatacji}

Eksperymentalna konstrukcja powłoki wiszącej powstała w celu przykrycia przestrzeni wykorzystywanej do prac modelowych przez studentów Uniwersytetu. Przykrycie stanowiło dobre zabezpieczenie przed wpływami atmosferycznymi, w szczególności przed nagrzewaniem słonecznym, bardzo intensywnym w tej strefie geograficznej . W trakcie kilkuletniej eksploatacji konstrukcji nie prowadzono niestety szczegółowych badań jej stanu technicznego. Jak wynika z relacji Wacława Zalewskiego, w powierzchni powłoki nie były zauważone pęknięcia ani rozwarstwienia betonu wypełniającego powłokę. Należy podkreślić, że w lokalnych warunkach atmosferycznych powłoka nie była narażona na destrukcyjne działanie zamarzania i rozmarzania wody opadowej, jak również nie była poddana obciążeniu śniegiem. W tych warunkach trudno przeanalizować wartości nośności powłoki na pionowe obciążenia zewnętrzne zwrócone ku dołowi. Natomiast obciążenie wiatrem było miarodajne dla sztywności powłoki obciążonej niesymetrycznie obciążeniem o kierunku poziomym z charakterystyką dynamiczną. Z tego przypadku obciążenia można wnioskować o dobrzej sztywności powłoki obciążonej od wewnątrz ssaniem wiatru skierowanym do góry. Okres obserwacji zrealizowanej konstrukcji eksperymentalnej został ograniczony do blisko pięciu lat. Ze względu na zmianę projektów inwestycyjnych Uniwersytetu nastąpiło rozebranie powłoki żelbetowej wraz z podporami łukowymi.. Poza dokumentacją zdjęciową na zachowała się prawdopodobnie dokumentacja techniczna ani badawcza tej oryginalnej konstrukcji wiszącej powłoki linowo- betonowej.

\section{Wnioski z eksperymentu}

Zrealizowana konstrukcja eksperymentalna należy do pionierskich projektów betonowych powłok wiszących. Przestrzenny kształt dwukrzywiznowej powłoki uzyskany w oparciu o logiczne wykorzystanie walorów statycznych stalowych łuków o złożonym przekroju średnicy o optymalnym charakterze systemu konstrukcyjnego. Wprowadzenie w układzie konstrukcyjnym aktywnego balansowania ciężaru powłoki przez wiszący pierścień obwodowy należy uznać za rozwiązanie oryginalne pod względem formy i technicznej wartości dla dynamicznej wartości konstrukcji eksperymentalnej. Potwierdzone okresem bezpiecznego użytkowania walory techniczne konstrukcji świadczą o prawidłowych założeniach teoretycznych przyjętych w fazie projektowej. Można uznać, że konstrukcja eksperymentalna tworzy zwarty system konstrukcyjny dla unikalnych przykryć obiektów ekspozycyjnych o funkcjach publicznych. Brak zachowanej dokumentacji budowli eksperymentalnej oraz niedostateczne jej przebadania skłania do kontynuowania badań obiektów o zbliżonych założeniach konstrukcyjnych. 
Planowane jest podjęcie dalszych badań modelowych i demonstracyjnych dla tego typu obiektów z zastosowaniem najnowszych technologii dostępnych w zakresie zbrojenia betonowych konstrukcji sprężonych oraz układania mieszanki betonowej poprzez drukowanie przestrzenne. Dla tego celu są prowadzone badania materiałowe nad nowymi recepturami dla betonów specjalnych. Uzyskania pozytywnych wyników planowanych prac badawczo-wdrożeniowych umożliwi w pełni potwierdzenie odkrywczych założeń konstrukcyjnych zdefiniowanych już pół wieku temu przez Wacława Zalewskiego'.

\section{Summary}

In the 1965 Waclaw Zalewski (1917-2016) designed an experimental structure consisting of compressed concrete shell hung on a hexagonal system of steel arches. Since at that time advance research tools were unavailable, the structure, considerably complicated from the static and technological point of view, had to be built in an experimental manner, based entirely on conceptual assumptions of Zalewski. Dynamic technical research accompanying the process of erecting the construction may be perceived as an early stage of the so called "form finding" - recently developing movement, which places the form of structures in the centre of interest. In the following consideration the technology and technical premises of the structure are going to be analysed. The experimental structure designed by Waclaw Zalewski at the University of Merida (Venezuela) drew significantly on the research models by Honoracio Caminos, devised as rubber membranes stretched over an artificial ring and upthrust by different configurations of internal support system distorting the flat rubber membrane.

In order to balance the internal ring, the breaklines between the rings of of the shell were run along the diagonals of the hexagon, so that rainwater could flow down the breaklines. The upper parts of the steel arches in the hexagonal system served at the same time as the breaking edge of the hang slings. Sectional roofing bent parallel to the curvature of the arches was added in order to shield this edge from the atmospheric conditions. The lower sections of the steel arches projecting in an open space beneath the surface of the shell formed a hexagonal system of $\mathrm{V}$-shaped columns supported in the corners of the hexagon. The arches of the hexagonal system were constructed from two bifurcating steel arches connected by steel elements assembled in a truss system. From the outside the structure formed a hanging shell, flowing down from the upper sections of the six arches towards the internal and external ring.

Concrete blocks situated in support points of the steel arches in the apexes of the hexagon served as the foundations of the experimental structure. While the horizontal forces of support reactions between the adjacent arches were to a large extent counterbalanced, only the vertical component of this reaction force needed to be transferred to the ground. Parabolic arches in the hexagonal system were double arches composed of C-shaped steel profiles. The parabolic shape was also rendered by the straight sections of steel beams welded together. The middle walls of C-profiles were situated on the external surface of the arches. The arches bifurcating upwards were connected by a spatial truss of steel bars, on whose lower rim the load-bearing slings were hung. The shape of the shell was corrected by relieving the load from the slings with hand-winches affixed to the steel arches. Concreting the shell was executed by hand-laying of consecutive layers of concrete, beginning with the perimeter ring of the shell. Suitable tension of the load-bearing slings was continuously corrected by increasing the degree of concreting in the trough of the internal ring. The long-lasting process of hand-concreting was performed without any technological breaks, which helped to obtain a monolithic concrete shell. The experimental structure was one of the first hanging concrete shells ever executed. The spatial bicurvate shape of the shell was obtained in accordance with a logical application of static qualities of steel arches characterised by complex diametral profile. Introducing an active counterbalancing of the shell load to the structural system was an innovative solution, both in terms of form and technology. The correctness of theoretical assumptions adopted in the design phase was confirmed by the period of safe usage. Further research on structures of similar kind is planned. Modern technologies employing compressed reinforced concrete or $3 \mathrm{D}$ concrete printing could be adopted in the execution of such structures. To this end material research on new concrete formulas is being conducted.

1 Zamieszczone w artykule fotografie pochodzą z archiwum domowego prof. Wacława Zaleskiego, który udostępnił je autorowi podczas konsultacji badawczych 
Abstract: Spatial structures are one of the most popular structural systems used to cover large spaces. Arrangement of the bars and nodes has a big influence on the distribution of forces inside the structure. Author was developing the method of dividing a surface which was called the energetic potential method. It is based on a natural process we know as the Coulomb Law. Using it we can create a self-optimizing structure where all of its nodes, mutually repulsing, are finally located in a similar distance to one another. Thanks to special computer program written by Author it was possible to generate a lot of structures with unique topology and after that could do a static analysis of them. After those it was found that some structures have a better ratio than popular structures so Author suppose that the method can have practical application in future [4].

Keywords: form of construction, reinforced concrete shell

\section{Bibliografia}

[1] Waclaw Zalewski and Edward Allen Shaping Structures Statics John Wiley and Sons, INC. New York 1998 